\title{
オイル阻集器の適正容量・構造に関する実験的研究 EXPERIMENTAL STUDY ON PROPER CAPACITY AND STRUCTURE OF THE OIL-INTERCEPTOR
}

\author{
小南和也*, 高地 進**, 小早川 香*** \\ Kazuya KOMINAMI, Susumu TAKACHI and Kaori KOBAYAKAWA
}

\begin{abstract}
Based on the knowledge that is acquired through basic experiment, the authors made full-scaled oil-interceptor and used conventional gasoline engine oil to conduct experiment. As a result, it is proved that to make oil-interceptor which can maintain retention efficiency to fulfill effluent standard of sewerage is feasible. Besides, the authors made consideration regarding performance test method of oil-interceptor based on this result of the experiment.
\end{abstract}

Keywords : Oil-Interceptor, Effluent standard, Capacity of oil, Capacity of sand, Retention Efficiency, Testing Method オイル阻集器, 排除基準, オイル量, 土砂量, 阻集性能, 試験方法

1. はじめに

1976 年 1 月 1 日から施行された“昭和 50 年建設省告示第 1597 号 (最終改定: 平成 12 年 5 月 20 日建設省告示第 1406 号) ”により、 污水がガソリン・油類（以下、オイルという）などの排水のために 配管設備の機能を著しく妨げる恐れがあるものを含む場合には、才 イル阻集器（以下、阻集器という）の設置が義務づけられている。

現在、阻集器の適正容量・構造の決定に際しては、空気調和・衛 生工学会規格“SHASE-S 206-2009「給排水衛生設備規準・同解説」 の「5.オイル阻集器の決定」が適用されており、その中で車 1 台 あたりのオイル量・土砂量などの基礎数值 ${ }^{1)}$, 2) が用いられている。

既報 ${ }^{3)}$ の基礎実験では、オイルの代わりに純正ラードを使用して、 公共下水道の排除基準を満足できる性能を保持した阻集器の作成の 可能性及び性能試験方法の規格化のための基礎的知見を得ることが できた。

そこで、基礎実験で得られたこれらの知見を基に、実際に阻集器 に流入するオイルを用いて、現状に適合した適正な容量・構造を備 えた阻集器の作成に向けて、実大阻集器により要求される性能につ いて実験を行うとともに、更に性能試験方法についての考察も行う。

\section{2. 実験概要}

阻集器の容量・構造は、図 1 に示寸ように上部に阻集されるオイ ルから成るオイル阻集層、流入する排水中のオイル（土砂）などを 排水と分離させるためのオイル (土砂) 分離層及び底部にたい積寸る 土砂から成る土砂たい積層の 3 層で構成されることになる。

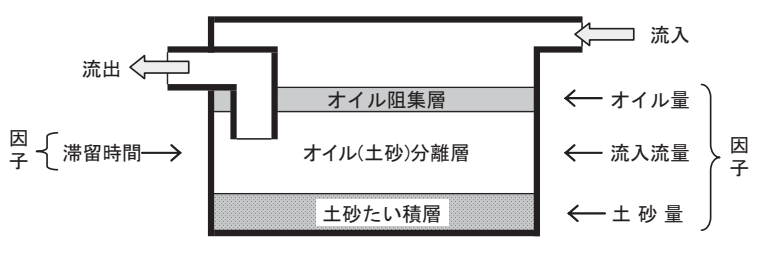

【器内要因】

【流入要因】

図 1 阻集器の容量・構造を決定するための要因

従って、これら各層の容量を決定するためには、流入要因として のオイル量、流入流量（水栓及び洗車機の使用水量）及び土砂量が 必要な因子となるとともに、器内要因としては、阻集器内に流入し たオイル及び土砂を排水と分離させるために貯留（滞留）しておく べき時間（以下、滞留時間という）が不可欠な因子となる。

そこで、阻集器のオイル阻集層、オイル(土砂) 分離層及び土砂た い積層の必要容量は、実態調查により得られた車 1 台あたりのオイ ル量、流入流量及び車 1 台あたりの土砂量(湿潤状態)を基に、(1) (3)式を用いて求められる。

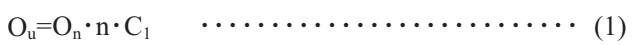

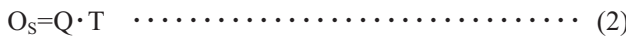

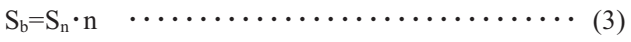

$$
\begin{aligned}
& \text { ここに、 } \mathrm{O}_{\mathrm{u}} \text { : オイル阻集層容量（L） } \\
& \mathrm{O}_{\mathrm{S}} \text { : オイル(土砂)分離層容量 }(\mathrm{L}) \\
& \mathrm{S}_{\mathrm{b}} \text { : 土砂たい積層容量（L) }
\end{aligned}
$$

\footnotetext{
* (財)日本建築総合試験所環境試験室 室長

** (株ピーエーシー環境モード 工博

****䝰)日本建築総合試験所環境試験室 工修 
$\mathrm{O}_{\mathrm{n}}:$ 車 1 台あたりのオイル量 $(\mathrm{g} /$ 台 $)$

$\mathrm{n}$ : 洗車台数 (台)

$\mathrm{C}_{1}$ : 単位換算值 $(\mathrm{L} / \mathrm{g})$

$\mathrm{Q}$ ：流入流量 $(\mathrm{L} / \mathrm{min})$

$\mathrm{T}$ ：滞留時間 $(\mathrm{min})$

$\mathrm{S}_{\mathrm{n}}$ : 車 1 台あたりの土砂量(湿潤状態)（L/台）

なお、 $\mathrm{O}_{\mathrm{n}} \cdot \mathrm{Q} \cdot \mathrm{S}_{\mathrm{n}}$ の各数值については、洗車実験結果 ${ }^{2)} に よ り 、$ $\mathrm{O}_{\mathrm{n}}$ はオイル量が最も多いワックス洗車の $10 \mathrm{~g} /$ 台、また $\mathrm{Q}$ は水栓口径 $13 \mathrm{~mm}$ の場合には $14 \mathrm{~L} / \mathrm{min} 、 14 \mathrm{~mm}$ の場合には $32 \mathrm{~L} / \mathrm{min}$ 、カーワッシャ の場合には仕様書明記の流量、そして、 $\mathrm{S}_{\mathrm{n}}$ は土砂量が最も多いワッ クス洗車の $0.09 \mathrm{~L} /$ 台、さらに、 $\mathrm{C}_{1}$ は $10^{-3} \mathrm{~L} / \mathrm{g}$ を用いる。

これより、オイル(土砂) 分離層においては、オイル及び土砂が排 水から分離できる滞留時間が必要となる。また、オイル阻集層及び 土砂たい積層においては、洗車台数に基べいて容量が確定すること になる。そこで、オイル及び土砂が排水から分離し、かつ、その分 離された容量が洗車台数から得られる容量を許容できるための必要 な条件（オイル及び土砂の阻集性能）について、実験により求める こととした。

また、排水が阻集器に流入した時に、水位面の上昇が起きること になるが、阻集器流入口は、この水位上昇面よりも高いことが必要 な条件となるので、流入流量と水位上昇との関係について、実験に より求めることとした。

そして、阻集器が屋外に設置された場合には、雨水が器内に流入 することになるので、雨水流入時における対応（阻集したオイルが 外部に流出しない）について、実験により検証することとした。

さらに、給油所に対しては、2006 年 4 月 1 日から斾行された“平 成 18 年総務省告示第 148 号 (危険物の規制に関する技術上の基準の 細目を定める告示の 部を改正する件）”により、「 定数量〔500L

(灯油または軽油を本.両に固定したタンクに注入するための固定注 油設備にあっては 900L) 〕の危険物が漏洩するものとした場合にお いて、当該危険物が滞留せず、完全に収容され、外部に流出しない ことを要件とする。と規定されたことから、大量オイル流入時にお ける対応（流入したオイルが外部に流出しない）について、実験に より検証することとした。なお、本実験は、2008 年 10 月より 2009 年 4 月に実施した。

以上に述べた実験内容をまとめると、次のようになる。
(1) オイル及び土砂の阻集性能実験
(2) 水位上昇実験
(3) 雨水流入洔における対応実験
(4) 大量オイル流入時における対応実験

\section{3. 実験装置及び実験用オイル}

実験装置は、SHASE-S 217-2008「グリース阻集器」の性能試験方 法で規定されている試験装置を用いた。なお、(オイル十土砂) 阻集 性能実験において、実験装置のうらグリースに代わるオイル投入器 については、流入させるオイル濃度自体が非常に低く、流入時間も 10 分間り長く、この間に一定の割合で投入を行う必要が女ることか ら可変タイプの送液ポンプを用いてオイルの投入を行うこととした。 実験装置の概要を図 2 に示す。

実験用オイルの選定に際しては、まず阻集器に流入すると考えら

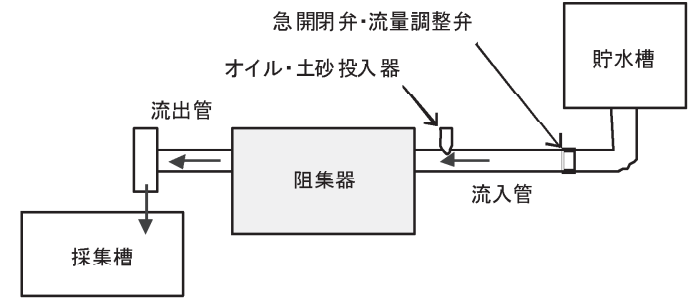

図 2 実験装置の概要

表 1 各種オイルの調查結果

\begin{tabular}{|c|c|c|}
\hline \multicolumn{2}{|r|}{ 種 類 } & \multirow{2}{*}{$\begin{array}{c}\begin{array}{c}\text { 密度 } \\
\left(\mathrm{g} / \mathrm{cm}^{3}\right)\end{array} \\
0.854\end{array}$} \\
\hline (1) & ガソリンエンジン油 & \\
\hline (2) & ディーゼルエンジン油 & 0.860 \\
\hline (3) & ギヤ一油 & 0.987 \\
\hline (4) & 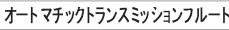 & 0.846 \\
\hline (5) & ブレーキ油 & 0.989 \\
\hline (6) & 不凍液 & 1.098 \\
\hline (7) & 自動車ガソリン & 0.783 \\
\hline (8) & 軽油 & 0.860 \\
\hline (9) & 灯油 & 0.795 \\
\hline (10) & 重油 & 0.894 \\
\hline (11) & 石油アスファルト & 1.000 \\
\hline (12) & 洗車ワックス & 1.002 \\
\hline (13) & 車ボディーワックス & 0.819 \\
\hline (14) & タイヤワックス & 0.988 \\
\hline (15) & ガソリエンジン廃油 & 0.858 \\
\hline (16) & 歯車潤滑油 & 0.883 \\
\hline (11) & 軸受潤滑油 & 0.973 \\
\hline (18) & 油圧作動油 & 0.870 \\
\hline & 平 均 & 0.909 \\
\hline
\end{tabular}

注)・密度は $15 \sim 20^{\circ} \mathrm{C}$ での值である。 ・ (15)の廃油は(1)の油を約 $7000 \mathrm{~km}$ 走行したものである。

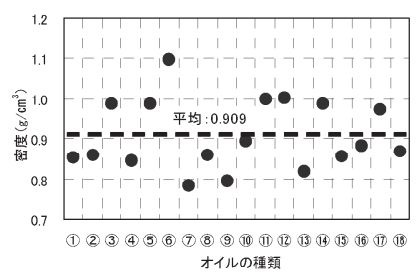

図 3 各種オイルの密度

表 2 実験用オイルの仕様

\begin{tabular}{|c|l|}
\hline 項 目 & \multicolumn{1}{c|}{ 仕 様 } \\
\hline メーカー & エクソンモービル社 \\
\hline 品 名 & $\begin{array}{l}\text { Vantage Pride III } \\
5 \mathrm{~W}-30\end{array}$ \\
\hline 密 度 & $0.854 \mathrm{~g} / \mathrm{cm}^{3} \quad\left(\right.$ at $\left.15^{\circ} \mathrm{C}\right)$ \\
\hline 粘 度 & $220 \mathrm{mPa} \cdot \mathrm{s}\left(\right.$ at. $\left.15^{\circ} \mathrm{C}\right)$ \\
\hline
\end{tabular}

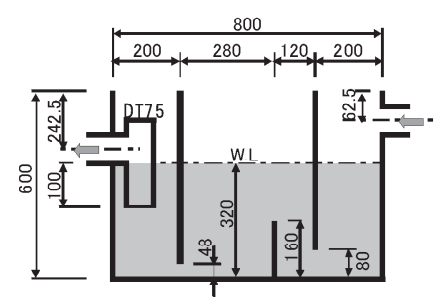

構造· 寸法図（寸法単位：mm)

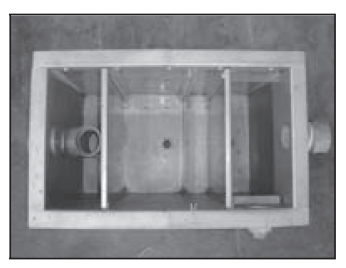

外 観
図 4 実験方法検討用阻集器

れる車などに使用されるオイルの種類と密度を調查・測定した。な お、オイル類は多種多様なものが市販され用いられており、その全 てのオイルを調查することは不可能でめる。そのため、本調查では 各種オイル類の販売量などを考慮して表 1 及び図 3 に示す 18 種類と 1, た。

これより、国内の車生産台数からガソリンエンジン車が車全体の 約 9 割を占めており、木場でのエンジンオイルの使用量が多いこと から、実験に用いるオイルとして(1)のガソリンエンジン油を選定し た。その仕様を表 2 に示す。

\section{4. 実験方法の検討}

\section{1 検討用阻集器}

実験方法の検討に用いた阻集器は、図 4 に示寸実容量 $102.4 \mathrm{~L}$ (内 法寸法: 長さ $800 \mathrm{~mm} \times$ 幅 $400 \mathrm{~mm} \times$ 高さ $600 \mathrm{~mm}$ 、水深 $320 \mathrm{~mm})$ のもので、 その内部構造壮 SHASE-S 206-2000「給排水衛生設備規準・同解説」 
の技術要項・同解説の「5. オイル阻集器の決定」における現場施 工阻集器の「隔板の設置位置」と同一形状とした。

\section{2 滞留時間の検討}

オイル (土砂) 分離層を対象として、オイルが排水上分離し、阻集 器から流出したオイル濃度が下水道法の排除基準である $5 \mathrm{mg} / \mathrm{L}$ を満 足するために必要となる滞留時間について検証することを目的とし た。

実験条件は、流入水として水道水（水温 $8 \sim 12^{\circ} \mathrm{C}$ ）を使用し、流 入水量を実容量 $(102.4 \mathrm{~L})$ 、投入才イル濃度を洗車実験結果 ${ }^{2}$ 上り排 水中のオイル濃度の最も高いワックス洗車の值である流入水量に対 して $0.1 \mathrm{~g} / \mathrm{L}(100 \mathrm{mg} / \mathrm{L}) 、$ 流入 1 回あたりの流入時間 (滞留時間)を 10 分間、5 分間及び 3 分間とLてて、各流入時間に対して流入開始から $10 \% 、 50 \%$ 及び $90 \%$ の経過時刻で、阻集器からの排出水を約 $1 \mathrm{~L}$ 採取 し、この作業を連続して 15 回（各流入回の間隔約 10 秒）行い、採 取したサンプルのオイル濃度〔ノルマルヘキサン抽出物質（鉱物油 類) 含有量〕を測定した。ノリマルヘキサン抽出物質 (鈗物油類) 含有 量の検定方法として「昭和 49 年環境省告示第 64 号付表 4 (平成 20 年改正)」を用い、定量下限值を $1 \mathrm{mg} / \mathrm{L}$ とし、定量下限值未満につ いては $1 \mathrm{mg} / \mathrm{L}$ 未満と記載した（以下、オイル濃度の分析結果は同様 とした)。その分析結果を表 3 に示す。

これより、ガソリンエンジン油では流出オイル濃度が下水道排除 基準の $5 \mathrm{mg} / \mathrm{L}$ を満足寸る滞留時間は 10 分間となる。また、この結 果は基礎実験 ${ }^{3)}$ で行った純正ラードにおける 20 回平均の実験内容 とほぼ等しく、併記した純正ラード 20 回平均の測定結果と概敃整合 している。

\section{3 排出水のサンプリング方法の検討}

排出水の採取方法については、JIS K 0102-2008「工場排水試験方 法」において、「水路、せき、溝、管などから落下している場合には、 試料を直接試料容器に受け、適切な空閒が残る程度に採取をとどめ る。」とのみ規定されていることから、具体的な採取方法について検 討することを目的とした。

排出水については、排出水全量ではなくサンプリングによる採取 となる。そのため、流入時間 (滞留時間)が 10 分間と長いため、流入 開始からどの経過時刻（採取時刻）で何回採取するのか、また流人 回数の何回目に採取するのかを決定するために下記の共通実験条件 で検討を行った。

[共通実験条件]

・ 流入時間 (滞留時間) : 10 分間

・ 流入水量 : 実容量相当 $(102.4 \mathrm{~L})$

・投入オイル濃度 : $100 \mathrm{mg} / \mathrm{L}$

\section{(1)流入開始からの採取時刻及び採取回数の検討}

流入回数を 15 回とし、最後の 15 回目の流入開始から 1 分後、5 分後及び 9 分後において、3 回連続して排出水を約 $1 \mathrm{~L}$ 採取し、オイ ル濃度〔ノルマルヘキサン抽出物質（鉱物油類）含有量]を分析した。 その分析結果を表 4 に示求。

(2)流入開始からの採取時刻及び流入回数の検討

流入回数 15 回とし、5 回目、10 回目及で 15 回目において、流 入開始から 1 分後、5 分後及び 9 分後に 1 回排出水を約 $1 \mathrm{~L}$ 採取し、 オイル濃度〔ノルマル人キサン抽出物質 (鉱物油類) 含有量〕を分析 した。その分析結果表 5 に示寸。
表 3 滞留時間の検証結果（単位 : $\mathrm{mg} / \mathrm{L}$ )

\begin{tabular}{|c|c|c|c|c|c|c|c|c|c|c|}
\hline \multirow{2}{*}{ 種 別 } & \multirow{2}{*}{$\begin{array}{l}\text { 滞留時間 } \\
\text { 経過時刻 }\end{array}$} & \multicolumn{3}{|c|}{10 分間 } & \multicolumn{3}{|c|}{5 分間 } & \multicolumn{3}{|c|}{3 分間 } \\
\hline & & $10 \%$ & $50 \%$ & $90 \%$ & $10 \%$ & $50 \%$ & $90 \%$ & $10 \%$ & $50 \%$ & $90 \%$ \\
\hline \multirow{5}{*}{$\begin{array}{c}\text { ガソリン } \\
\text { エンジン } \\
\text { 油 }\end{array}$} & 5 回目 & 1 & 1 & 2 & 3 & 5 & 8 & 6 & 10 & 6 \\
\hline & 10 回目 & 1 & 2 & 2 & 6 & 6 & 8 & 6 & 9 & 4 \\
\hline & 15 回目 & 1 & 1 & 1 & 7 & 6 & 6 & 7 & 7 & 7 \\
\hline & \multirow{2}{*}{15 回平均 } & 1.0 & 1.3 & 1.7 & 5.3 & 5.7 & 7.3 & 6.3 & 8.7 & 5.7 \\
\hline & & \multicolumn{3}{|c|}{1.3} & \multicolumn{3}{|c|}{6.1} & \multicolumn{3}{|c|}{6.9} \\
\hline 純正ラード & 20 回平均 & \multicolumn{3}{|c|}{2.8} & \multicolumn{3}{|c|}{4.1} & \multicolumn{3}{|c|}{6.8} \\
\hline
\end{tabular}

表 6 (3の検討における

表 4 (1)の倹討における オイル濃度の測定結果

\begin{tabular}{|c|c|c|c|}
\hline \multirow{2}{*}{ 採取回数 } & \multicolumn{3}{|c|}{ 流入開始からの採取時間 } \\
\cline { 1 - 4 } & 1 分間 & 5 分間 & 9 分間 \\
\hline 1 回目 & 1 & 1 & 3 \\
\hline 2 回目 & 1 & 1 & 3 \\
\hline 3 回目 & 1 & 1 & 1 \\
\hline
\end{tabular}

表 5 (2)の検討における オイル濃度の測定結果

\begin{tabular}{|c|c|c|c|}
\hline \multirow{2}{*}{ 流入回数 } & \multicolumn{3}{|c|}{ 流入開始からの採取時間 } \\
\cline { 2 - 4 } & 1 分間 & 5 分間 & 9 分間 \\
\hline 5 回目 & 1 & 1 & 2 \\
\hline 10 回目 & 1 & 2 & 2 \\
\hline 15 回目 & 1 & 1 & 1 \\
\hline
\end{tabular}

注)・表 4〜6のオイル濃度の測定結果 の単位は、 $\mathrm{mg} / \mathrm{L}$ である。

測定回数 オイル濃度

\begin{tabular}{|c|c|}
\hline 1 回目 & 1 未満 \\
\hline 2 回目 & 1 \\
\hline 3 回目 & 1 \\
\hline 4 回目 & 1 未満 \\
\hline 5 回目 & 1 未満 \\
\hline 6 回目 & 1 未満 \\
\hline 7 回目 & 1 未満 \\
\hline 8 回目 & 1 未満 \\
\hline 9 回目 & 1 \\
\hline 10 回目 & 1 未満 \\
\hline 11 回目 & 1 未満 \\
\hline 12 回目 & 1 未満 \\
\hline 13 回目 & 1 未満 \\
\hline 14 回目 & 1 未満 \\
\hline 15 回目 & 1 未満 \\
\hline 16 回目 & 1 \\
\hline 17 回目 & 1 \\
\hline 18 回目 & 1 \\
\hline 19 回目 & 1 \\
\hline 20 回目 & 1 \\
\hline
\end{tabular}
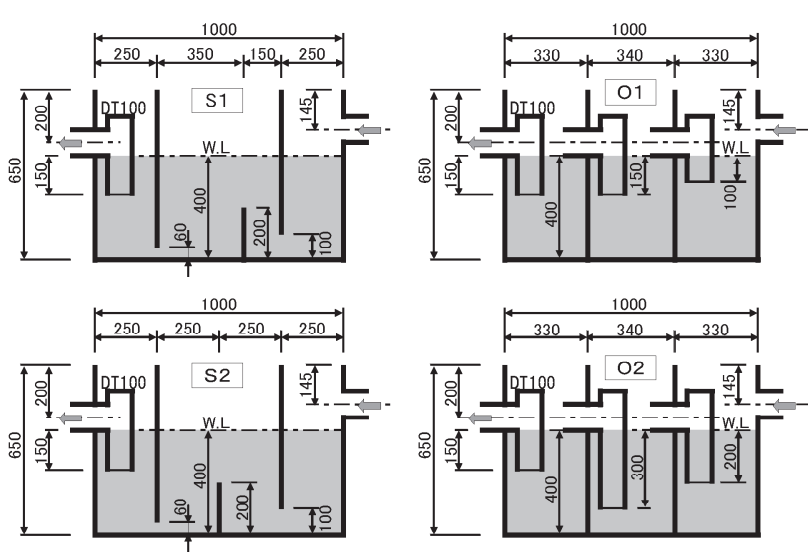

$\stackrel{1000}{2250} \underset{250}{2} \underset{250}{\longrightarrow 250}$

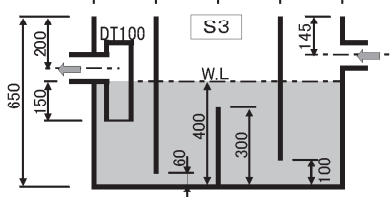

注) $\mathrm{S} 1 \sim \mathrm{S} 3$ : 連続槽形 01，02：独立槽形

図 5 実験用阻集器の構造・寸法図（寸法単位：mm）
連続槽形 $(\mathrm{S} 2)$

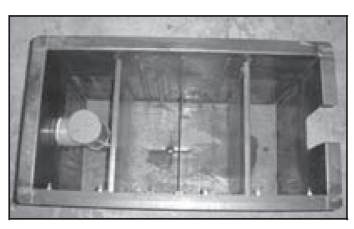

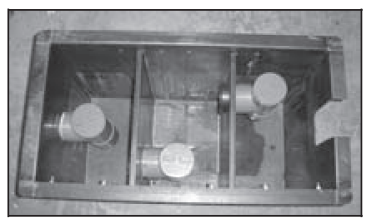

独立槽形 $(\mathrm{O} 1)$
写真 1 実験用阻集器の外観 


\section{(3)流入回数の検討}

流入回数を 20 回とし、流入開始から 9 分後に 1 回排出水を $1 \mathrm{~L}$ 採 取し、オイル濃度〔ノルマルヘキサン抽出物質 (鉱物油類) 含有量〕 を分析した。その分析結果を表 6 に示す。

これより、(1)及び(2)の結果を二元配列の分散分析により検証を行 ったが、採取時刻、採取回数及び流入回数それぞれに有意な差は認 められなかった。また、流入回数 20 回目まではオイル濃度に差は認 められなかったため、最小限での実験回数で試験は実施できるもの と考え、オイル及び土砂の阻集性能実験における排出水の採取方法 としては、流入回数 6 回目から 10 回目について、その流入開始から 9 分後に 1 回採取し、合計 5 回分のサンプリングと寸ることにした。

\section{5. 実験方法}

\section{1 実験用阻集器}

実験用阻集器の作成にあたっては、表 7 に示寸基本設計条件 ${ }^{3)}$ と し、駐車場に設置する阻集器で一番需要の多い実容量 $200 \mathrm{~L}$ のの を想定した。

阻集器の構造・寸法は、図 5 及び写真 1 に示寸内法寸法が長さ 1000 $\mathrm{mm} \times$ 幅 $500 \mathrm{~mm} \times$ 高さ $650 \mathrm{~mm}$ 、水深 $400 \mathrm{~mm}$ のもとした。その内部構造 は SHASE-S 206-2000「5. オイル阻集器の決定」の現場施工の阻集 器における「隔板の設置位置」に準じ、たい積する土砂を阻集器底 部から立ち上がっている仕切板で阻集させることを目標として、土 砂のたい積層容量を 3 仕様（S1～S3）に変化させた連続槽形のもの と、給油所に設置する消防機関が指導している連通管による 3 槽と し、たい積する土砂を 1 槽目にたい積させる（O1）及び 1,2 槽目に たい積させる（O2）の 2 仕様に変化させた独立槽形のものとした。 阻集器のそれぞれの仕様における計算上の土砂たい積層容量（実 容量分率）を表 8 に示す。

\section{2 土砂及びオイルの阻集性能実験}

阻集性能実験は、土砂の阻集性能を確認したうえで、オイルの阻 集性能を検証する手順で進めた。なお、阻集性能の基準值に関して は、オイルについては下水道法の排除基準である $5 \mathrm{mg} / \mathrm{L}$ と、また、 土砂についてはグリース阻集器における阻集効率が、ドイツ規格の “旧 DIN4040 及び 4042(1957 年)”では累積阻集効率として 92\%以 上 ${ }^{4)}$ となっており、これを参考として $95 \%$ を採用することとした。

\section{（1）土砂の阻集性能}

土砂の阻集性能の実験条件を表 9 に示す。なお、実験に用いた土 砂は、過去の基礎実験 ${ }^{3)}$ などで採取したたい積土砂の中心粒度に近 く、安定した粒度分布 (図6 参照) が得られるものとした。

測定は、流入回数を 5 回繰り返した後、阻集器から流出した土砂 を網ふるい(目開き $75 \mu \mathrm{m})$ に受けて乾燥させた後、質量を測定した。 これより、土砂の阻集効率（阻集器に阻集された土砂量／投入土砂

量）を算出した。

\section{（2）オイルの阻集性能}

オイルの阻集性能の実験条件を表 10 に示す。測定は、阻集器中間 槽の上部にオイル阻集層容量（実容量の $2.5 \%$ 相当）のオイルをあら かじめ保持させておき、流入回数 5 回までは排水の採取は行わず、 流入回数 6 回から 10 回について、流入開始 9 分後に阻集器からの排 出水を約 $2 \mathrm{~L}$ 採取した。その採取したサンプルについて、オイル濃 度〔ノルマルヘキサン抽出物質 (鉱物油類) 含有量〕を分析した。
表 7 阻集器の基本設計条件

\begin{tabular}{|l|l|}
\hline \multicolumn{1}{|c|}{ 項 目 } & \multicolumn{1}{c|}{ 内 } \\
\hline 寸法比率 & 長さ: 幅 : 水深=2: $1: 0.8$ \\
\hline 流入流量 & $15 \mathrm{~L} / \mathrm{min} 〔>$ 水栓 $13 \mathrm{~mm}(14 \mathrm{~L} / \mathrm{min})]$ \\
\hline オイル阻集層 & 実容量の $2.5 \%$ \\
\hline オイル (土砂) 分離層 & 実容量の $75 \%$ \\
\hline 土砂たい積層 & 実容量の $22.5 \%$ \\
\hline
\end{tabular}

表 8 阻集器の土砂たい積層容量

\begin{tabular}{|c|c|c|c|c|c|}
\hline \multirow{2}{*}{ 阻 集 器 } & \multicolumn{3}{|c|}{ 連続槽形 } & \multicolumn{2}{|c|}{ 独立槽形 } \\
\cline { 2 - 6 } & $\mathrm{S} 1$ & $\mathrm{~S} 2$ & $\mathrm{~S} 3$ & $\mathrm{O} 1$ & $\mathrm{O} 2$ \\
\hline $\begin{array}{c}\text { 土砂たい積層容量 } \\
(\text { 実容量分率\%) }\end{array}$ & 20 & 25 & 37.5 & 24.8 & 25 \\
\hline
\end{tabular}

表 9 土砂の阻集性能の実験条件

\begin{tabular}{|c|c|}
\hline 項 目 & 件 \\
\hline 流 入 水 & 水道水 \\
\hline 流入水量 & 実容量の 75\% (オイル(土砂)分離層容量相当) \\
\hline 流入時間 & 1 分間 \\
\hline 投入土砂 & $\begin{array}{l}\text { 相馬産硅砂 } 5 \text { 号（密度 1.34） } \\
\text { (中心粒度 : } 300 \mu \mathrm{m} \text { 、分布 } 106 \sim 600 \mu \mathrm{m} \text { ) }\end{array}$ \\
\hline 土砂投入量 & 流入水量に対して $13.4 \mathrm{~g} / \mathrm{L} \quad(10 \mathrm{cc} / \mathrm{L})$ \\
\hline 流入回数 & 30 回（土砂たい積層容量／投入土砂量） \\
\hline
\end{tabular}

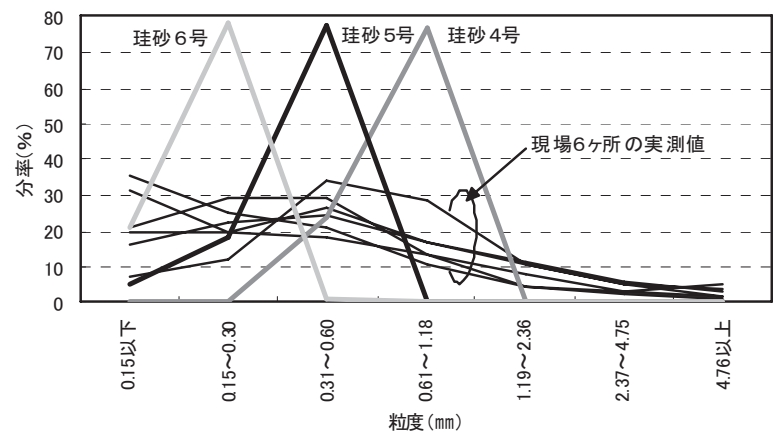

図 6 たい積土砂及び実験用土砂の粒度分布

表 10 オイルの阻集性能の実験条件

\begin{tabular}{|l|l|}
\hline \multicolumn{1}{|c|}{ 項 目 } & \multicolumn{1}{|c|}{ 条 件 } \\
\hline 流入 & 水道水 \\
\hline 流入水量 & 実容量の $75 \%$ (オイル (土砂) 分離層容量相当) \\
\hline 流入時間 & 10 分間 \\
\hline 投入オイル & ガソリンエンジン油 (密度 0.854$)$ \\
\hline オイル投入量 & 流入水量に対して $0.1 \mathrm{~g} / \mathrm{L}(100 \mathrm{mg} / \mathrm{L})$ \\
\hline 流入回 数 & 10 回 \\
\hline
\end{tabular}
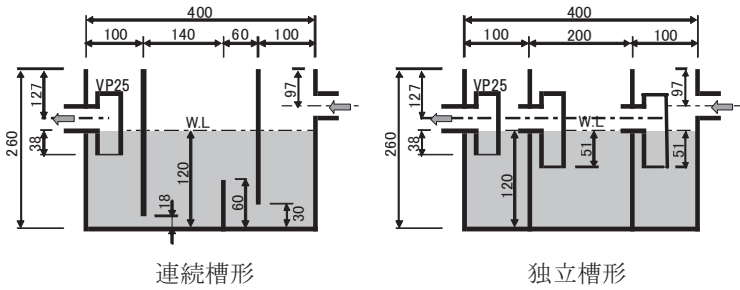

独立槽形

図 7 小型阻集器の構造・寸法図（寸法単位 : mm)

\section{3 水位上昇実験}

阻集器に排水が流入した場合の流入時間当りの流入水量と標準水 位面からの上昇水位との関係を求めることを目的とした。

実験は、流入水として水道水を用い、流入時間を 1 分間とし、水 
量を実容量比の 5 段階に変化させて流し、阻集器の各槽における標 準水位面からの最高水位上昇高さを測定した。測定方法は、鋼尺（最 小目盛 $1 \mathrm{~mm}$ ）を用い、阻集器側面の各槽に標準水位面を基準（0）と なるように取付け、上昇水位の最高高さをmm単位で読み取った。実 験条件の詳細は以下のとおりである。

・流入時間 : 1 分間

- 流入水量 : 実容量の $50 \%, 75 \%, 100 \%, 125 \%, 150 \%$

\section{4 雨水流入時の対応実験}

阻集器に雨水が流入した場合において、すでに阻集器内に保持さ れているオイルの流出が防止できるかどうかを検証することを目的 とした。

実験に際しては、実験用阻集器では大量の水量を使用することに なるので、適確な実験を実施するために阻集器の容量をできるだけ 小さくする必要があることから、図 7 に示すような実容量 $9.6 \mathrm{~L}$ の小 型阻集器（連続槽形及び独立槽形）2 機種を用いた。なお、連続槽 形では内部構造を実験用阻集器の S1 と同一形状（ただし、寸法比 率にうち水深を 0.8 から 0.6 に変更）とし、独立槽形では連続槽形 と各槽寸法を同一とした。

実験は、阻集器中間槽の上部にオイル阻集層として予めオイルを 保持させておき、流入水として水道水を用い、流入流量を変化させ て、阻集器からの排出水を容器に約 $1 \mathrm{~L}$ 採取してオイル濃度〔ノル マルヘキサン抽出物質（鉱物油）含有量〕を分析した。実験条件の 詳細は以下のとおりである。

・保持オイル量 : 実容量の $5 \%, 10 \%, 15 \%, 20 \%$

- 流入流量 : 1 分間当り実容量の 2 倍, 3 倍, 4 倍, 5 倍

- 流入時間 : 10 分間

\section{5 大量オイル流入時の対応実験}

オイル (土砂) 分離層を対象として、阻集器内に大量にオイルが流 入した場合において、その流入したオイルが阻集器外に流出しない かどうかを確認することを目的とした。

実験は、雨水流入時の対応実験と同様に実験用阻集器では大量の オイルを使用することになるので小型阻集器 2 機種を用い、両阻集 器ともに阻集器内に水道水のみを貯え、最大のオイル阻集層容量相 当のオイルのみを流入口から投入し、阻集器からの排出水を全て採 集し、これを攪汼して容器に約 $1 \mathrm{~L}$ 採取してオイル濃度〔ノルマル ヘキサン抽出物質（鉱物油類）含有量〕を分析した。実験条件の詳 細は以下のとおりである。

・オイル阻集層容量 : $6.496 \mathrm{~L}(5826.9 \mathrm{~g})$

・投入時間： $15 \mathrm{sec}, 30 \mathrm{sec}, 60 \mathrm{sec}$

\section{6. 実験結果及び考察}

\section{1 オイル及び土砂の阻集性能実験}

\section{（1）土砂の阻集性能}

土砂の阻集性能の実験結果を図 8 に、実験終了時の土砂のたい積 状況を写真 2 に示す。その結果、連続槽形（S1～S3）の阻集効率は 99.5\%以上で安定しており、3 仕様ともほぼ同程度の性能である。ま た、独立槽形の阻集効率は、O1 で 98.9\%以上、O2 で 96.9\%以上で あり、連通管の吸込口が阻集器底部に近いために土砂が吸込まれや すいものと考えられる。

土砂のたい積状況は、連続槽形の S1 では、阻集器底部から立ち



図 8 土砂の阻集性能実験結果
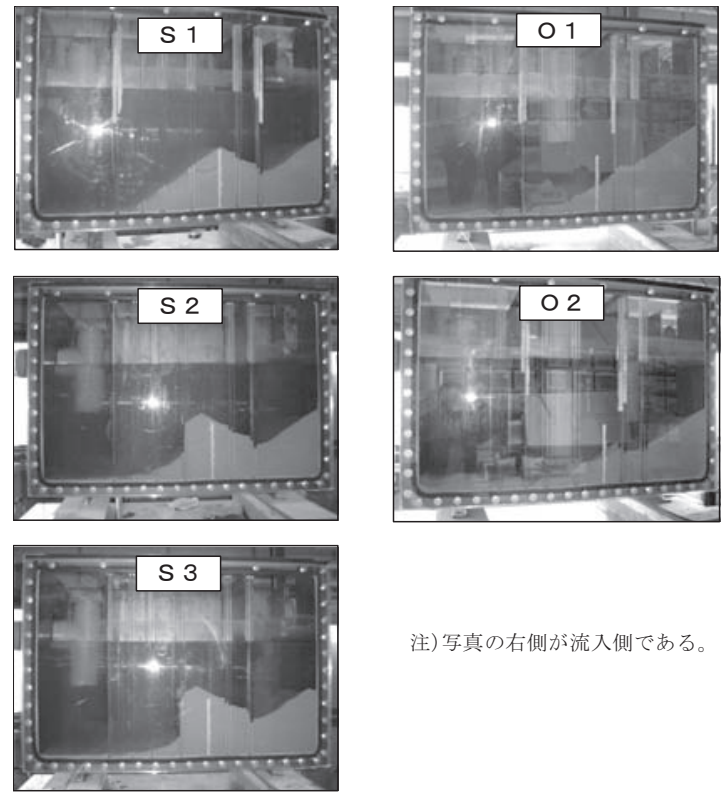

注)写真の右側が流入側である。

写真 2 土砂のたい積状況（実験終了時）

表 11 オイルの阻集性能分析結果

\begin{tabular}{|c|c|c|c|c|c|}
\hline \multirow{3}{*}{ 流入回数 } & \multicolumn{3}{|c|}{ オイル濃度 } & \multicolumn{2}{|l|}{$[\mathrm{mg} / \mathrm{L}]$} \\
\hline & \multicolumn{3}{|c|}{ 連続槽形 } & \multicolumn{2}{|c|}{ 独立槽形 } \\
\hline & S1 & $\mathrm{S} 2$ & S3 & $\mathrm{O} 1$ & $\mathrm{O} 2$ \\
\hline 6 回目 & 1 未満 & 1 未満 & 1 未満 & 1 末満 & 1 未満 \\
\hline 7 回目 & 1 未満 & 1 未満 & 1 未満 & 1 未満 & 1 未満 \\
\hline 8 回目 & 1 未満 & 1 未満 & 1 未満 & 1 未満 & 1 未満 \\
\hline 9 回目 & 1 未満 & 1 未満 & 1 未満 & 1 未満 & 1 未満 \\
\hline 10 回目 & 1 未満 & 1 未満 & 1 未満 & 1 未満 & 1 未満 \\
\hline
\end{tabular}


(1) 連続槽形
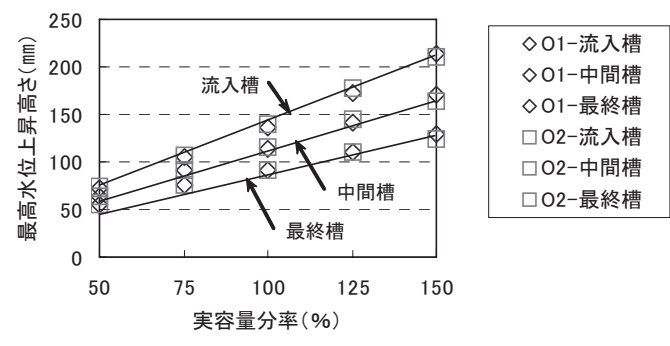

(2) 独立層形

図 9 水位上昇実験結果 
上がっている仕切板を超えてたい積しているが、S2 及び S3 では 仕切板を超えてたい積している量は少ない。これより、土砂たい 積層容量はS2 の実容量比 $25 \%$ 以上を確保しておれば土砂を流入 側で阻集でき、清掃等の維持管理も容易に行えるものと考えられ る。また、独立槽形では連続槽形よりも最終槽のたい積量が多く なっている。これは独立槽形の方が槽内の流速が速く、その水流 により土砂がより流下側に運ばれるためと考えられる。

\section{（2）オイルの阻集性能}

オイルの阻集性能の分析結果を表 11 に示す。その結果、いずれの 仕様ともにオイル濃度は $1 \mathrm{mg} / \mathrm{L}$ 未満を示しており、下水道法の排除 基準である $5 \mathrm{mg} / \mathrm{L}$ は満足することが確認できた。

\section{2 水位上昇実験}

各阻集器の流入槽・中間槽及び最終槽における 1 分当りの流入水 量に対する実容量に基づくパーセント表示（以下、実容量分率(\%) という）と最高水位上昇高さの関係を図 9 に示す。

その結果、標準水位面からの最高水位上昇高さは、連続槽形及び 独立槽形ともに流入水量と比例関係にあり、連続槽形はそれぞれ内 部構造に関係なく各槽間の高低差はほとんどない反面、独立槽形は 各槽間での高低差が認められた。これは、隔板に設けられた開口面 積の違いによるものと考えられる。

各阻集器における流入水量の実容量分率と最高水位上昇高さの相 関関係（回帰式及び相関係数）を表 12 に示す。

\section{3 雨水流入時の対応実験}

各阻集器からの排出水のオイル濃度の分析結果を表 13 に示寸。 その結果、2 機種とも全ての実験条件でオイル濃度が $1 \mathrm{mg} / \mathrm{L}$ 未満 となった。これは、保持オイル量が設計の 8 倍である $20 \%$ の状態で、 尚且つ 1 分間当り実容量の 5 倍の流量を流しても、両阻集器ともに オイルがほとんど流出しないということとなり、一旦保持されたオ イルは相当量の流量が短時間に流入しても阻集器外に流出せず、そ の保持状態を維持できるものと考えられる。なお、この結果は純正 ラードで実施した基礎実験結果 ${ }^{3)}$ とも整合している。

\section{4 大量オイル流入時の対応実験}

各阻集器から流出したオイル濃度の分析結果を表 14 に、投入時間 $15 \sec$ の場合における阻集器内のオイルの流動状況を写真 3 に示す。 その結果、2 機種とも全ての実験条件でオイル濃度が $1 \mathrm{mg} / \mathrm{L}$ 未満 となり、写真 3 からも判るように阻集器の最終槽にはオイルが流入 していない。これより、流入すると考えられる最大のオイル量以上 のオイル (土砂) 阻集層容量を確保することにより、大量オイルが流 入した場合でも十分対応できるものと考えられる。なお、この結果 は純正ラードで実施した基礎実験結果 ${ }^{3)}$ とも整合している。

\section{7. 性能試験方法についての考察}

前項の実験結果より、雨水及び大量オイル流入時における対応に ついては、設計段階(図面)で確認することが可能なため、阻集器の 性能試験としては、オイル及び土砂の阻集性能並びに水位上昇を求 めることが必要となる。

試験に際しては、試験阻集器の申請事項として寸法、実容量、才 イル阻集層容量、オイル(土砂)分離層容量、土砂たい積層容量及び 滞留時間が必要となる。そして、オイル及び土砂の阻集性能試験方 法としては、 5.2 に基づいて試験を実施する。なお、土砂の阻集性
表 12 実容量分率と最高水位上昇高さの相関関係

\begin{tabular}{|c|c|c|c|}
\hline 阻集器 & 槽 & 回帰式 & 相関係数 \\
\hline 連続槽形 & 全て & $\mathrm{Y}=0.976 \mathrm{x}$ & 0.977 \\
\hline \multirow{3}{*}{ 独立槽形 } & 流入 & $\mathrm{Y}=1.404 \mathrm{x}$ & 0.999 \\
\cline { 2 - 4 } & 中間 & $\mathrm{Y}=1.144 \mathrm{x}$ & 0.992 \\
\cline { 2 - 4 } & 最終 & $\mathrm{Y}=0.897 \mathrm{x}$ & 0.961 \\
\hline
\end{tabular}

注) $\mathrm{Y}$ : 最高水位上昇高さ $(\mathrm{mm}) 、 \mathrm{x}$ : 実容量分率 $(\%)$

表 13 雨水流入時のオイル濃度分析結果

\begin{tabular}{|c|c|c|c|c|}
\hline \multirow[b]{2}{*}{ No. } & \multirow{2}{*}{$\begin{array}{c}\text { 保持オイル量 } \\
\text { (実容量分率) }\end{array}$} & \multirow{2}{*}{$\begin{array}{c}\text { 流入流量 } \\
\text { (1 分間当りの } \\
\text { 実容量比) }\end{array}$} & \multicolumn{2}{|c|}{ オイル濃度 $(\mathrm{mg} / \mathrm{L})$} \\
\hline & & & 連続槽形 & 独立槽形 \\
\hline 1 & $5 \%$ & 2 倍 & 1 未満 & 1 未満 \\
\hline 2 & \multirow{2}{*}{$10 \%$} & 2 倍 & 1 未満 & 1 未満 \\
\hline 3 & & 5 倍 & 1 未満 & 1 未満 \\
\hline 4 & $15 \%$ & 2 倍 & 1 未満 & 1 未満 \\
\hline 5 & \multirow{4}{*}{$20 \%$} & 2 倍 & 1 未満 & 1 未満 \\
\hline 6 & & 3 倍 & 1 未満 & 1 未満 \\
\hline 7 & & 4 倍 & 1 未満 & 1 未満 \\
\hline 8 & & 5 倍 & 1 未満 & 1 未満 \\
\hline
\end{tabular}

表 14 大量オイル流入時のオイル濃度分析結果

\begin{tabular}{|c|c|c|}
\hline 阻集器 & 投入時間 $(\mathrm{sec})$ & オイル濃度 $(\mathrm{mg} / \mathrm{L})$ \\
\hline 連続槽形 & $15 、 30 、 60$ & 全て 1 未満 \\
\hline 独立槽形 & $15 、 30 、 60$ & 全て 1 未満 \\
\hline
\end{tabular}



(1)連続槽形 オイル投入終了 60 秒後

(2)独立槽形

写真 3 大量オイル流入時のオイルの流動状況 (投入時間 15 秒の場合)

能試験に際しては、試験条件について表 9 のちで変更となる項目 は、以下のとおりである。

-「流入水量」は、「流入流量」として、申請オイル(土砂) 分離層容 量を 1 分間で除した值 $[\mathrm{L} / \mathrm{min}]$

-「流入回数」は、申請土砂たい積層容量を流入回数 1 回あたりに 投入する土砂量で除した回数

また、オイルの阻集性能試験に際しては、阻集器中間層の上部に 申請オイル阻集層容量のオイルを予め保持させた後、試験条件につ いて表 10 にうちで変更となる項目は、以下のとおりである。

・「流入水量」は、「流入流量」として、申請オイル(土砂) 分離層容 量を滞留時間で除した值 $[\mathrm{L} / \mathrm{min}]$

・「流入時間」は、申請滞留時間[min]

次に、上昇水位試験方法としては、5.3 に基づいて試験を実施す る。なお、上昇水位試験に際しては、測定は阻集器第 1 槽 (流入槽) 
において行い、回帰式を求める。

さらに阻集器の選定は、次の手順で進められる。まず、阻集器に 流入する流量と、洗車台数に基づき(1)及び(3)式を用いて、オイル阻 集層容量及び土砂たい積層容量を算出する。そして、オイル及び土 砂の阻集性能試験結果から得られる許容流入流量、許容オイル阻集 量及び許容土砂たい積層が算出されたそれぞれの值を満足する阻集 器を選出する。そのうえで、雨水が流入する場合にはその雨水流量、 また雨水が流入しない場合には洗車流量の值を、水位上昇試験結果 から得られる回帰式に代入し、最高水位上昇高さを求め、その高さ 以上の位置に流入口を設置することにより、適正な容量・構造を備 えた阻集器が決定される。

\section{8.まとめ}

実大阻集器を用い、実際のガソリンエンジン油を使用して実施し た各種実験結果より、以下の知見が得られた。

1) 実験に使用するオイルは、ガソリンエンジン油を用いることがで きる。

2) 阻集器からの流出オイル濃度を測定するための排出水のサンプ リングは、採取時刻、採取回数及び流入回数ともに有意な差は認 められず、最小限での実験回数で測定できる。

3) 流出オイル濃度が下水道排除基準の $5 \mathrm{mg} / \mathrm{L}$ を満足するための滞 留時間は、基本的に 10 分間を必要とする。

4) 土砂の阻集性能は、連続槽形は 99.5\%以上を示し、独立槽形は、 96〜99\%程度であり、その内部構造の違いにより若干の差が認め られる。また、土砂たい積層の容量を仕切板までで実容量比 $25 \%$ の容量を確保すれば、ほとんどの土砂を流入側で阻集することが できる。

5) 標準水位面からの最高水位上昇高さは、連続槽形及び独立槽形と もに流入水量と比例関係にある。また、上昇水位は独立槽形の方 が連続槽形よりも上がりやすく、阻集器内部の各槽間の水位差も 大きい。

6) 雨水流入時において、実験に用いた阻集器では保持オイル量が設 計の 8 倍、流入流量が実容量の 5 倍となっても、一旦保持された オイルは阻集器外に流出せず、保持状態を維持できることが確認 できた。これより、雨水が短時間で大量に阻集器に流入しても、 阻集器内に保持されているオイルは流出しにくいと考えられる。

7) 大量オイル流入時でも、実験に用いた阻集器では流入したほとん どのオイルが阻集器外に流出しないことが確認できた。これより、 流入すると考えられる最大のオイル量以上のオイル (土砂) 分離 層容量を確保することにより、流入オイルを十分収集できると考 えられる。

8) 雨水流入及び大量オイル流入時の性能については、実験により検 証する必要はなく、設計段階で十分に対応することが可能である。

9) 阻集器の性能は、オイル及び土砂の阻集性能試験並びに水位上昇 試験を実施することにより評価できる。

以上の実験結果より、阻集器より流出するオイル濃度が下水道の 排除基準である $5 \mathrm{mg} / \mathrm{L}$ 未満を満足できる阻集器の作成は十分可能で あることが判明した。また、現状に適した適正容量・構造を備えた 阻集器の作成については、阻集器に要求される性能のうち土砂及び
オイルの阻集性能並びに水位上昇は試験により、雨水流入及び大量 オイル流入時の性能は設計段階で対応可能となった。

今後は、給油所等に設置する大型の阻集器についても今回と同様 の実験により検証し、阻集器の設計及び性能試験方法の規格化を図 りたい。

\section{謝辞}

本実験は、日本阻集器工業会に設けられたオイル阻集器研究委員 会の活動の一環で行われた。本実験に際し、実験用阻集器の作成を 担当頂いた岡崎隆氏に感謝の意を表します。また、工業会関係者に 多大なご協力を頂き、ここに感謝の意を記します。

\section{参考文献}

1) (社)空気調和・衛生工学会：SHASE-S 206-2009「給排水衛生設備規準・同 解説」, 丸善, 2009.6

2) 小南和也・高地進・小早川香 : オイル阻集器の容量算定における基礎数值 に関する洗車実験, 日本建築学会環境系論文集, Vol.73, No.624, pp.229-235, 2008.2

3) 小南和也・高地進・小早川香 : オイル阻集器の適正容量・構造に関する基 礎実験, 日本建築学会環境系論文集, Vol.74, №.639, pp.635-641, 2009.5

4) (社)空気調和・衛生工学会 : SHASE-S 217-2008「グリース阻集器」, 2008.9

5) (社)空気調和・衛生工学会：SHASE-S 206-2000「給排水衛生設備規準 - 同 解説」, 丸善, 2000.3

6) JIS K 0102-2008「工場排水試験方法」，2008.3

7) 石川栄助：実務家のための新統計学, 1970.3, 梖書店

8) 高地進・小南和也・小早川香・岡崎隆 : オイル阻集器の適正容量・構造に 関する基礎研究 その 1 実験の背景及び概要, 日本建築学会大会学術講 演梗概集 D-1，pp.691-692，2008.9

9) 小南和也・高地進・小早川香・岡崎隆 : オイル阻集器の適正容量・構造に 関する基礎研究 その 2 オイル及び土砂の阻集性能, 日本建築学会大会 学術講演梗概集 D-1, pp.693-694, 2008.9

10)小早川香・高地進・小南和也・岡崎隆 : オイル阻集器の適正容量・構造に 関する基礎研究 その 3 水位上昇、雨水及び大量オイル流入に対寸る性 能, 日本建築学会大会学術講演梗概集 D-1, pp.665-666, 2009.8

11)高地進・小南和也・小早川香・岡崎隆 : オイル阻集器の阻集性能に関寸る 実大実験 その 1 実験概要及び流出オイル測定方法の検討, 日本建築学 会大会学術講演梗概集 D-1, pp.667-668, 2009.8

12)小南和也・高地進・小早川香・岡崎隆 : オイル阻集器の阻集性能に関する 実大実験 その 2 土砂及びオイルの阻集性能の実験結果, 日本建築学会 大会学術講演梗概集 D-1, pp.669-670, 2009.8

13)小南和也・高地進・小早川香・岡崎隆 : オイル阻集器の要求性能に関する 実験 （第 1 報）土砂及びオイルの阻集性能の実験結果, 空気調和・衛生 工学会大会学術講演論文集, pp.763-766, 2009.9

14)高地進・小南和也・小早川香・岡崎隆 : オイル阻集器の要求性能に関する 実験 （第 2 報）水位上昇、雨水及び大量オイル流入に対する性能の実験 結果, 空気調和・衛生工学会大会学術講演論文集, pp.767-770, 2009.9

15)森村武雄、高地進ほか：オイル阻集器（ガソリントラップ）の適正容量に 関する調査研究報告書, 空気調和・衛生工学, 1970.2

16)高地進: 各種阻集器の特性, 空気調和・衛生工学, Vol.57, No.5, pp.21-26, 1983.5

(2009年10月 8 日原稿受理，2010年 1 月 8 日採用決定） 